\title{
Safety-relevant hydrogeological properties of the claystone barrier of a Swiss radioactive waste repository: An evaluation using multiple lines of evidence
}

\author{
Andreas Gautschi ${ }^{1}$ iD
}

Received: 2 February 2017 / Revised: 16 March 2017 / Published online: 26 June 2017

(C) The Author(s) 2017. This article is an open access publication.

\begin{abstract}
In Switzerland, the Opalinus Clay - a Jurassic (Aalenian) claystone formation - has been proposed as the first-priority host rock for a deep geological repository for both low- and intermediate-level and high-level radioactive wastes. An extensive site and host rock investigation programme has been carried out during the past 30 years in Northern Switzerland, comprising extensive 2D and 3D seismic surveys, a series of deep boreholes within and around potential geological siting regions, experiments in the international Mont Terri Rock Laboratory, compilations of data from Opalinus Clay in railway and motorway tunnels and comparisons with similar rocks.

The hydrogeological properties of the Opalinus Clay that are relevant from the viewpoint of long-term safety are described and illustrated. The main conclusions are supported by multiple lines of evidence, demonstrating consistency of conclusions based on hydraulic properties, porewater chemistry, distribution of natural tracers across the Opalinus Clay as well as small- and large-scale diffusion models and the derived conceptual understanding of solute transport.
\end{abstract}

Keywords Opalinus Clay · Hydraulic conductivity · Diffusion · Porewater $\cdot$ Natural tracers $\cdot$ Self-sealing

Andreas Gautschi

andreas.gautschi@nagra.ch,

andrega-geoscienceconsulting@bluewin.ch

1 National Cooperative for the Disposal of Radioactive Waste (Nagra), Hardstraße 73, 5430 Wettingen, Switzerland
Sicherheitsrelevante hydrogeologische Eigenschaften der Tonsteinbarriere eines Schweizer Tiefenlagers für radioaktive Abfälle: Eine Evaluation anhand mehrfacher Argumentationslinien

Zusammenfassung In der Schweiz wurde der Opalinuston - eine jurassische (Aalenium) Tonstein-Formation - als prioritäres Wirtgestein für geologische Tiefenlager (Endlager) für radioaktive Abfälle vorgeschlagen, sowohl für schwach- und mittelaktive Abfälle, wie auch für hochaktive Abfälle. Während der letzten 30 Jahren wurden in der Nordschweiz umfangreiche Standort- und Wirtgesteinsuntersuchungen durchgeführt, mit 2D- und 3D-reflexionsseismischen Untersuchungen, einer Serie von Tiefbohrungen in und im Umfeld der potenziellen geologischen Standortgebiete, Experimenten im internationalen Felslabor Mont Terri und Kompilationen von Daten aus Opalinustonstrecken in Straßen- und Eisenbahntunneln.

Die hydrogeologischen Eigenschaften des Opalinustons, die unter dem Gesichtspunkt der Langzeitsicherheit relevant sind, werden beschrieben und veranschaulicht. Die wichtigsten Schlussfolgerungen sind durch mehrere Argumentationslinien unterstützt und zeigen ein konsistentes Gesamtbild von hydraulischen Eigenschaften, Porenwasserchemie, Verteilung natürlicher Tracer sowie klein- und großmaßstäblicher Diffusionsmodelle und den abgeleiteten konzeptionellen Modellvorstellungen.

\section{Introduction}

In Switzerland, the Nuclear Energy Act requires the disposal of all radioactive waste in deep geological repositories. The Swiss programme foresees two types of reposi- 
tories: one for low- and intermediate-level waste (L/ILW) and one for high-level waste (HLW) consisting of spent fuel, vitrified high-level waste and long-lived intermediatelevel waste with the option to dispose of all wastes in one repository - the so-called combined repository. The engineered barrier system for L/ILW and for long-lived ILW is concrete-based and, in the HLW repository, the disposal canisters (carbon steel or copper-coated carbon steel) are surrounded by compacted bentonite (Nagra 2016).

The procedure for selecting the repository sites is defined in the Sectoral Plan for Deep Geological Repositories (Swiss Federal Office of Energy 2008) and is managed by the Swiss Federal Office of Energy. Nagra, the Swiss National Cooperative for the Disposal of Radioactive Waste, is the responsible implementer and conducts all necessary site investigations, safety assessments and studies related to construction feasibility. The Sectoral Plan foresees the selection of sites in three stages, the third stage leading to the granting of a general licence. Stage 1 of the Sectoral Plan concluded with the proposal of four different sedimentary host rocks for the L/ILW repository; the Opalinus Clay formation in Northern Switzerland was selected for the HLW repository (Nagra 2008a, 2008b). Nagra also proposed three geological siting regions for the HLW repository and six for the L/ILW repository; all siting regions and potential host rocks were approved by the Federal Government in November 2011. Currently, the envisaged repository depth in these sites is between 400 and $900 \mathrm{~m}$. The minimum depth is related to possible erosion scenarios in the siting region, the maximum depth to issues in the context of construction feasibility (for details see Nagra 2014a and ENSI 2017).

The ongoing Stage 2 of the Sectoral Plan aims at narrowing down the potential geological siting regions. Nagra's proposals were submitted and published by the SFOE in January 2015 (Nagra 2014a, 2014b, 2014c). Of the six L/ILW regions and three HLW regions identified in Stage 1, Nagra proposed the two regions, Jura Ost and Zürich Nordost, for further investigation (Fig. 1). The other four siting regions would also meet the safety requirements, but they were placed in reserve because in relative terms they showed clear disadvantages from a safety viewpoint. The disadvantages include limited length of migration pathways, challenges due to great depth of the repository and less favourable situation with respect to erosion and neotectonics. ENSI (the Swiss Federal Nuclear Safety Inspectorate) and its experts reviewed the submitted documents (ENSI 2017). ENSI approved Nagra's proposals for: (a) the choice of Opalinus Clay as the host rock for both repository types, (b) the two regions for further investigation in Stage 3, (c) placing three of the remaining four regions in reserve, but (d) recommended to include in addition Nördlich Lägern in Stage 3 (Fig. 1). The review continues with a review by federal commissions and a broad public consultation. A final decision by the Swiss Federal Council on the result of Stage 2 is expected at the end of 2018.

In Stage 3, the remaining sites will be investigated in detail, with 3 to 5 deep boreholes per site comprising extensive test programmes and 3D seismic surveys.

\section{Lithology, mineralogy and porosity of the Opalinus Clay}

The Jurassic (Aalenian) Opalinus Clay formation - named after the ammonite Leioceras opalinum - was deposited in an epicontinental shallow marine environment (Wetzel and Allia 2003) and has a thickness of $80-130 \mathrm{~m}$ in boreholes in Northern Switzerland. It consists of dark grey to black, partly silty claystones that are subdivided into several lithostratigraphic units based on the content of thin calcareous silty-sandy lenses or siderite nodules (Nagra 2002a). Compared to other Mesozoic sedimentary rocks in the area, it is a very homogeneous formation with rather small vertical and lateral lithological variability. At the decimetre to millimetre scale, the preferred alignment of platy clay particles is responsible for a distinct fabric ('bedding') which causes anisotropic hydraulic and mechanical properties.

The average clay mineral content of the Opalinus Clay is $59 \pm 12$ (mean value in wt.- $\% \pm 1$ sigma, for details see Nagra 2014b, Dossier VI), consisting of illite $(22 \pm 8 \%)$, illite/smectite mixed layers $(13 \pm 7 \%)$, kaolinite $(19 \pm 6 \%)$ and chlorite $(7 \pm 3 \%)$. Other main components are quartz $(20 \pm 6 \%)$ and calcite $(14 \pm 10 \%$, partly bioclasts, partly diagenetic cement); siderite and feldspars are in the range of a few \%. Important accessory components are pyrite (1.2 \pm $0.9 \%)$, dolomite/ankerite $(0.6 \pm 0.2 \%)$ and organic carbon $(0.7 \pm 0.4 \%)$.

The Opalinus Clay was subject to a complex burial history (Mazurek et al. 2006), during which a maximum depth of 1650-1700 m was reached in the area of the potential siting regions in Northern Switzerland in the Swiss Molasse Basin and the Tabular Jura, and approximately $1350 \mathrm{~m}$ in north-west Switzerland in the area of the Mont Terri underground rock laboratory (URL) located in the Jura Foldand-Thrust Belt (Fig. 1).

The porosity of the Opalinus Clay reflects the burial history, with values in the range of $11-12 \%$ in the area of the potential siting regions with deeper maximum burial and approx. $12-18 \%$ in the Mont Terri URL with somewhat shallower maximum burial. The porosity values are based on water-loss measurements at $105^{\circ} \mathrm{C}$ or on bulk and grain density measurements (definitions and nomenclature of porosities in clay rocks are addressed in more detail in Nagra 2014b, Dossier VI, Ch. 2.3.1.1). Pore sizes (equivalent pore radii) are mainly in the range of $1-25 \mathrm{~nm}$ (Nagra 2002a, Ch. 5.4 and Nagra 2014b, Dossier VI, Ch. 2.3). 


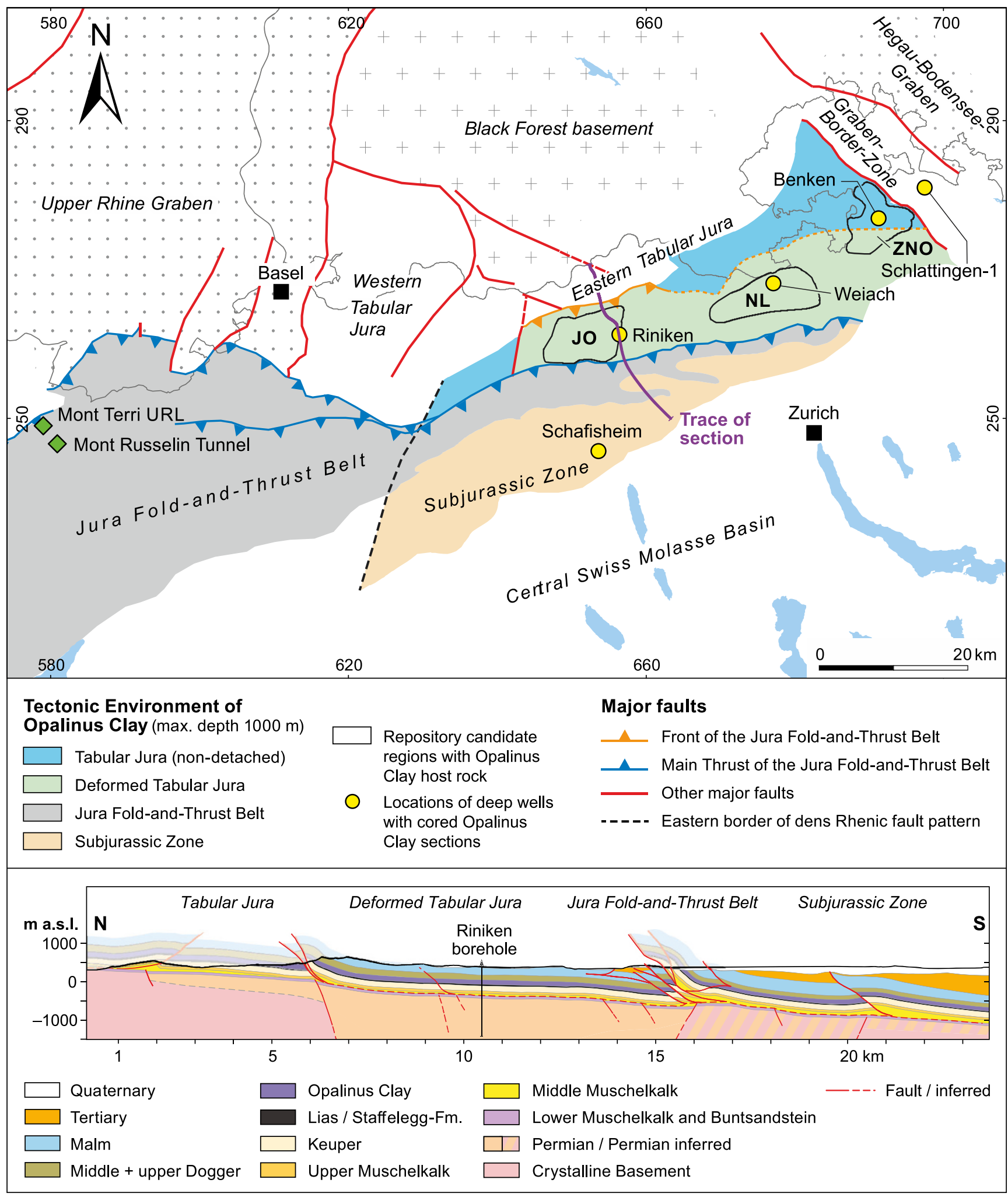

Fig. 1 Tectonic environment of the Opalinus Clay in Northern Switzerland (modified after Nagra 2014b) and locations of deep boreholes and tunnels with investigations of Opalinus Clay. Candidate siting regions: ZNO Zürich Nordost, NL Nördlich Lägern, JO Jura Ost 


\section{Porewater geochemistry}

\section{Origin of Opalinus Clay porewaters}

Diffusion has been shown to be the dominant mechanism of solute transport in the Opalinus Clay and in other clayrich formations (Gimmi et al. 2007; Mazurek et al. 2011). Driven by concentration gradients, the porewater of the Opalinus Clay adjusts slowly to changing conditions in the adjacent aquifers. While the characteristics of mobile groundwaters in aquifers may change rapidly in response to evolving surface conditions and climate, porewaters in clay-rich formations are geochemical archives with a much longer memory. Thus, the porewater composition in the Opalinus Clay is, on the one hand, a result of chemical interaction (buffering) with solid phases and, on the other hand, it reflects the palaeo-hydrogeological evolution in the embedding aquifers since deposition of the formation at 174 Ma (e. g. Nagra 2002a, Ch. 4.8; Pearson et al. 2003). The most thorough attempt to reconcile all available hydrogeochemical and isotopic data of the Opalinus Clay in the Mont Terri/Mont Russelin area is provided by Mazurek and De Haller (2017) by unravelling the complex palaeohydrogeological evolution in great detail. It is shown that Opalinus Clay porewaters are not simple binary mixtures of seawater and meteoric water, but their chloride and stable water isotope signatures can potentially be explained by the addition of a component of partially evaporated seawater, followed by mixing with meteoric water. While the Bromide/Chloride ratios of the porewaters in the Mont Terri/ Mont Russelin area are in the range of modern seawater, the ratios of Opalinus Clay porewaters in Northern Switzerland do not have a marine signature (Pearson and Waber 2001). This indicates a different palaeohydrogeological evolution of the Mont Terri/Mont Russelin and Northern Switzerland realms.

\section{Methodology for deriving a 'reference porewater' for safety assessment}

A thorough understanding of the porewater chemistry of a host rock is indispensable for the assessment of radionuclide solubility and retention. However, the extremely low permeability of claystones places limitations on the artefactfree sampling of porewaters. For this reason, the complete composition of a clay porewater cannot be derived directly from measured concentrations, a measured $\mathrm{pH}$ value and partial pressure of $\mathrm{CO}_{2}$. While measured concentrations of conservative (non-reactive) species, such as chloride, are considered to closely represent in-situ values, assumptions on the saturation state with respect to relevant minerals (calcite, dolomite, celestite, quartz, fluorite, pyrite, siderite) are made for non-conservative (reactive) species. A few param- eters need to be estimated based on expert opinion, such as the partial pressure of $\mathrm{CO}_{2}$. The measured occupancy and selectivity of the cation exchange site population on clay minerals is directly related to the cation proportions in the porewater and can also be taken into account in the geochemical models.

A fundamental understanding of the porewater chemistry of the Opalinus Clay was built up through extensive investigations in the Mont Terri Rock Laboratory and investigations on drillcores in the laboratory (Pearson et al. 2003).

Based on this, and taking into account data from cores of the Benken borehole which is located in the Zürich Nordost siting region (Nagra 2002a, Ch. 5.12), Mäder (2009) used geochemical model calculations to define a so-called 'reference porewater' as the basis for the safety assessment, covering the possible variation of porewaters in the Opalinus Clay of Northern Switzerland, as well as the higher salinity porewaters observed in the Mont Russelin tunnel mentioned below (Table 1). In order to reduce the uncertainties, Pearson et al. (2011) emphasised the need to improve geochemical modelling efforts, e.g. by a more detailed identification of controlling phases in the Opalinus Clay (including clay minerals and redox-sensitive elements) together with an evaluation of their thermodynamic properties or by the measurement of the composition and the stability constants of clay minerals that are present in the formation.

\section{Porewater salinity, chloride content}

An intrinsic property of claystones lies in the electrostatic interactions of the permanently negatively charged clay surfaces with dissolved substances; this results in a reduction of the porosity accessible to anions (e. g. Appelo and Wersin 2007; Altmann et al. 2012). Details on this topic in the context of the Opalinus Clay and implications for porewater sampling are summarised and discussed in Wersin et al. (2013), Van Loon (2014) and Mazurek et al. (2015).

For the porewater salinities of the Opalinus Clay in Northern Switzerland, the proportion of the anion-accessible pore space is around $50 \%$ of the total pore space, while the other half is anion-free (bound) water.

The salinity of the porewater in the Opalinus Clay varies both in the vertical dimension and, with much lower gradients, also laterally. It depends strongly on the evolution of the salinity in the aquifers above and below (see also section on 'natural tracer profiles'). For the 'reference porewater' of the Opalinus Clay in Northern Switzerland, the maximum chloride value from the Benken borehole was selected $(0.16 \mathrm{~mol} / \mathrm{kg} \approx 6 \mathrm{~g} / \mathrm{kg})$. This is less than half of the maximum content in the Mont Terri Rock Laboratory $(0.4 \mathrm{~mol} / \mathrm{kg} \approx 14 \mathrm{~g} / \mathrm{kg}$; Pearson et al. 2003; Mazurek et al. 2011) and much less than the maximum chloride content 
Table 1 Porewater compositions of the Opalinus Clay (Mäder 2009; updated for Nagra 2014b, Dossier VI, also taking into account fluorite saturation)

\begin{tabular}{llllll}
\hline & & $\begin{array}{l}\text { Reference } \\
\text { (Benken) }\end{array}$ & $\begin{array}{l}\text { High pCO } \\
(\text { Benken })\end{array}$ & $\begin{array}{l}\text { Low pCO } \\
\text { (Benken) }\end{array}$ & $\begin{array}{l}\text { High salinity } \\
\text { (Mont Russelin) }\end{array}$ \\
\hline $\mathrm{pH}$ & - & 7.20 & 7.00 & 7.50 & 7.01 \\
$\mathrm{p} \varepsilon$ & - & -2.78 & -2.55 & -3.13 & -2.56 \\
$\mathrm{Eh}$ & {$[\mathrm{mV}]$} & -164 & -150 & -185 & -151 \\
$\mathrm{Ionic} \mathrm{strength}$ & {$\left[\mathrm{mol} / \mathrm{kg}_{\mathrm{H} 2 \mathrm{O}}\right]$} & 0.23 & 0.23 & 0.23 & 0.76 \\
$\mathrm{log} \mathrm{pCO}_{2}$ & {$[\mathrm{bar}]$} & -2.20 & -1.80 & -2.80 & -2.50 \\
$\mathrm{Na}$ & {$\left[\mathrm{mol} / \mathrm{kg}_{\mathrm{H} 2 \mathrm{O}}\right]$} & $1.64 \mathrm{E}-01$ & $1.65 \mathrm{E}-01$ & $1.64 \mathrm{E}-01$ & $5.28 \mathrm{E}-01$ \\
$\mathrm{~K}$ & {$\left[\mathrm{~mol} / \mathrm{kg}_{\mathrm{H} 2 \mathrm{O}}\right]$} & $2.60 \mathrm{E}-03$ & $2.62 \mathrm{E}-03$ & $2.60 \mathrm{E}-03$ & $1.77 \mathrm{E}-03$ \\
$\mathrm{Mg}$ & {$\left[\mathrm{mol} / \mathrm{kg}_{\mathrm{H} 2 \mathrm{O}}\right]$} & $9.65 \mathrm{E}-03$ & $9.77 \mathrm{E}-03$ & $9.55 \mathrm{E}-03$ & $3.76 \mathrm{E}-02$ \\
$\mathrm{Ca}$ & {$\left[\mathrm{mol} / \mathrm{kg}_{\mathrm{H} 2 \mathrm{O}}\right]$} & $1.25 \mathrm{E}-02$ & $1.27 \mathrm{E}-02$ & $1.24 \mathrm{E}-02$ & $4.97 \mathrm{E}-02$ \\
$\mathrm{Sr}$ & {$\left[\mathrm{mol} / \mathrm{kg}_{\mathrm{H} 2 \mathrm{O}}\right]$} & $2.11 \mathrm{E}-04$ & $2.12 \mathrm{E}-04$ & $2.09 \mathrm{E}-04$ & $4.22 \mathrm{E}-04$ \\
$\mathrm{Fe}$ & {$\left[\mathrm{mol} / \mathrm{kg}_{\mathrm{H} 2 \mathrm{O}}\right]$} & $5.24 \mathrm{E}-05$ & $5.43 \mathrm{E}-05$ & $5.09 \mathrm{E}-05$ & $2.46 \mathrm{E}-04$ \\
$\mathrm{Cl}$ & {$\left[\mathrm{mol} / \mathrm{kg}_{\mathrm{H} 2 \mathrm{O}}\right]$} & $1.60 \mathrm{E}-01$ & $1.60 \mathrm{E}-01$ & $1.60 \mathrm{E}-01$ & $6.62 \mathrm{E}-01$ \\
$\mathrm{~F}$ & {$\left[\mathrm{~mol} / \mathrm{kg}_{\mathrm{H} 2 \mathrm{O}}\right]$} & $1.53 \mathrm{E}-04$ & $1.52 \mathrm{E}-04$ & $1.53 \mathrm{E}-04$ & $1.11 \mathrm{E}-04$ \\
$\mathrm{~S}$ & {$\left[\mathrm{~mol} / \mathrm{kg}_{\mathrm{H} 2 \mathrm{O}}\right]$} & $2.47 \mathrm{E}-02$ & $2.47 \mathrm{E}-02$ & $2.47 \mathrm{E}-02$ & $2.11 \mathrm{E}-02$ \\
$\mathrm{C}$ & {$\left[\mathrm{mol} / \mathrm{kg}_{\mathrm{H} 2 \mathrm{O}}\right]$} & $2.51 \mathrm{E}-03$ & $4.15 \mathrm{E}-03$ & $1.21 \mathrm{E}-03$ & $1.06 \mathrm{E}-03$ \\
$\mathrm{Si}$ & {$\left[\mathrm{mol} / \mathrm{kg}_{\mathrm{H} 2 \mathrm{O}}\right]$} & $1.78 \mathrm{E}-04$ & $1.78 \mathrm{E}-04$ & $1.79 \mathrm{E}-04$ & $1.72 \mathrm{E}-04$ \\
\hline
\end{tabular}

observed at Mont Russelin of $0.66 \mathrm{~mol} / \mathrm{kg} \approx 23 \mathrm{~g} / \mathrm{kg}$ (Koroleva et al. 2011). More recent data from the Schlattingen1 borehole in Northern Switzerland (Wersin et al. 2013) show similarly moderate salinities as those in Benken. It is expected that the salinities in the Opalinus Clay of the potential siting regions in Northern Switzerland will not significantly exceed those of the reference porewater of Benken. Nevertheless, a highly saline variant of the reference porewater based on the situation at Mont Russelin (Table 1) takes into account the uncertainty related to the salinity evolution in the aquifers overlying and underlying the Opalinus Clay. This uncertainty also affects the predictability of the vertical salinity profiles across the region of interest.

\section{Redox conditions}

Redox conditions strongly affect the mobility and sorption of redox-sensitive radionuclides in a nuclear waste repository, such as uranium, neptunium, plutonium, technetium and selenium. Generally, reducing conditions are favourable with respect to suppressing solubilities and promoting retention of radionuclides (e. g. Altmaier and Vercouter 2012; Berner 2014a, 2014b, Baeyens et al. 2014a, 2014b).

During repository construction and operation, oxygen will be introduced into the repository system. After a relatively short initial oxic phase (for the Swiss HLW repository $<1$ year, Garitte et al. 2016), the conditions will become and remain reducing due to iron corrosion and pyrite oxidation in the repository near-field, provided that reducing conditions prevail in the undisturbed pristine clay host rock (Wersin et al. 2003; Bradbury et al. 2014).

Determining the redox state and redox-active reactions of porewaters in clay rocks is not straightforward. Redox measurements in the Opalinus Clay in the Mont Terri URL were carried out over nearly 20 years. Pearson et al. (2003) summarise the early experience, while later developments and the improvement in the understanding of the measurement results are documented in Wersin et al. (2011a, 2011b) and in a series of papers in a special issue of Applied Geochemistry (Volume 26, Issue 6, June 2011). The most challenging issues in measuring redox conditions are $\mathrm{O}_{2}$ gas contamination at trace level in laboratory glove boxes, glycerol release from the gel filling of reference electrodes or electrode drift, unknown or not measured redox-sensitive species and co-existing redox couples providing mixed redox potentials; the understanding and the modelling of the redox conditions can thus be very challenging. There is also a correlation between $\mathrm{pH}$ and redox potential, depending on the specific redox-active chemical couple, which is implicit in the interpretative and predictive modelling of redox.

Despite trying several approaches to collect in situ $\mathrm{pH}$ and redox potential data, none of them were entirely satisfactory (Pearson 2009). For this reason, Eh values were calculated assuming that ferrous iron is controlled by pyrite and siderite equilibria for an upper and lower limit of $\mathrm{CO}_{2}$ partial pressure (or $\mathrm{pH}$ respectively) and for a given (measured) sulphate content (Mäder 2009) (Table 1). These are thought to be relatively robust assumptions. 


\section{Radionuclide solubility and retention}

The long-term safety of radioactive waste repositories in clay rocks relies mainly on a very low solubility of the waste form and an effective interplay between slow advection and diffusion, as well as strong nuclide retention. For the Swiss case, the solubilities and sorption coefficients of all safetyrelevant radionuclides have been evaluated during Phase 2 of the Sectoral Plan (Berner 2014a, 2014b; Baeyens et al. 2014a, 2014b).

Under reducing conditions, the $\mathrm{UO}_{2}\left(\right.$ and $\mathrm{PuO}_{2}$ ) pellets in the spent fuel have very low solubilities, and, because of the very low quantities of mobile porewater present in the engineered bentonite barrier and in the Opalinus Clay, the masses dissolved are likely to be exceedingly small (Bradbury et al. 2014), i. e. except for the instant release fraction (IRF), the fission products trapped in the pellets are only released very slowly. The IRF consists of those radionuclides that are released from spent fuel immediately upon canister breaching. It is the combined release of radionuclides from grain boundaries and cracks of the spent fuel pellets and from the gap between the pellets and the cladding (Nagra 2002b, Fig. 4.5-2).

Under reducing conditions, the most radiotoxic actinides have very low solubilities and they are also strongly sorbed on clay minerals in the bentonite backfill and in the clayrich host rock. In combination with slow advection and diffusion (see sections below), sorption will retard transport of many positively charged ionic species of radionuclides until complete decay within a few metres distance from the waste canister surface (e.g. Nagra 2002b, Fig. 6.6-2; Grambow 2016). Only negatively charged long-lived radionuclide ions $\left({ }^{129} \mathrm{I},{ }^{79} \mathrm{Se},{ }^{36} \mathrm{Cl}\right)$ or neutral species $\left({ }^{14} \mathrm{C}\right.$ in small organic molecules) can migrate through the natural barrier system because they are non-sorbing or weakly sorbing (Nagra 2002b). These nuclides also determine the annual individual radiation dose to the local population, which is quantified by dose calculations for different scenarios of a safety case (Nagra 2002b).

\section{Hydraulic properties}

\section{Hydraulic packer tests in boreholes and laboratory tests on cores}

An extensive database is available for the Opalinus Clay from hydraulic packer tests in boreholes (Fig. 2). Data are available from three Nagra deep boreholes in Northern Switzerland (data compilation in Nagra 2010, Tab. A31), from numerous boreholes drilled in all directions in the Mont Terri Rock Laboratory (Jaeggi et al. 2014; Yu et al. 2017) and from shallow boreholes in the Swabian

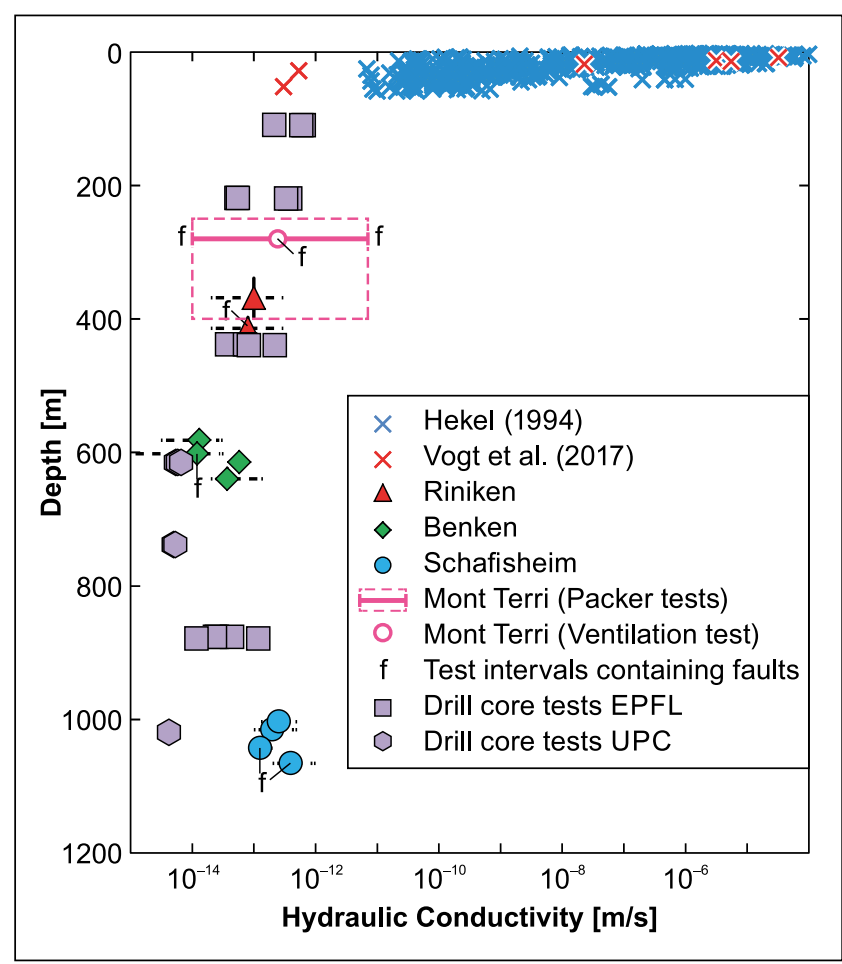

Fig. 2 Hydraulic conductivity of the Opalinus Clay in Northern Switzerland versus depth: Results from double packer tests in boreholes, from a large-scale ventilation test in the Mont Terri URL and from selected laboratory tests on drillcores (average experimental confining pressure converted to depth). EPFL samples: Ferrari et al. (2012), UPC samples: Romero and Gómez (2013)

Alb in Germany (Hekel 1994). The hydraulic conductivity of the Opalinus Clay is depth-dependent (Fig. 2). Near the surface, it can have $\mathrm{K}$ values up to $10^{-4} \mathrm{~m} / \mathrm{s}$ due to decompaction effects and weathering processes. At depths between 10 and $30 \mathrm{~m}, \mathrm{~K}$ decreases by several orders of magnitude. This decrease correlates with a marked increase in the chloride content of the porewaters which confirms that slow groundwater movement has persisted for a very long period (Hekel 1994). There are no data from hydraulic tests in boreholes for depths between 50 and $250 \mathrm{~m}$. The most comprehensive and reliable dataset comes from the Benken exploratory borehole where the Opalinus Clay was encountered in a depth of 539-652 m (Nagra 2001; Beauheim 2013). It shows consistent $\mathrm{K}$ values with little scatter, typically between $2 \cdot 10^{-14}$ and $1 \cdot 10^{-13} \mathrm{~m} / \mathrm{s}$. These values are more than 1000 times lower than the minimum requirements for the hydraulic conductivity of host rocks for HLW in the German and the Swiss site selection programmes: $\mathrm{K}<10^{-10} \mathrm{~m} / \mathrm{s}$ (AkEnd 2002, Tab. 4.1; Kommission Lagerung hochradioaktiver Abfallstoffe 2016, Kap. 6.5.5.1), $\mathrm{K}_{\mathrm{V}} \leq 10^{-10} \mathrm{~m} / \mathrm{s}$ (Nagra 2008b, Tab. 4.2-1). In the German programme $\mathrm{K}$ values $<10^{-12} \mathrm{~m} / \mathrm{s}$ are classified as 'favourable' (AkEnd 2002, Tab. 4.3; Kommission Lagerung hochradioaktiver Abfälle 2016, Tab. 25). 
Fig. 3 Cores of faulted sections in the Opalinus Clay in the Riniken (left) and Schafisheim (right) boreholes. The depth of the cores is indicated above/ below the cores. Red arrows: Fault planes. The hydraulic conductivity measured by double packer tests in these sections is comparable with tests in undisturbed sections (cf. Fig. 2)

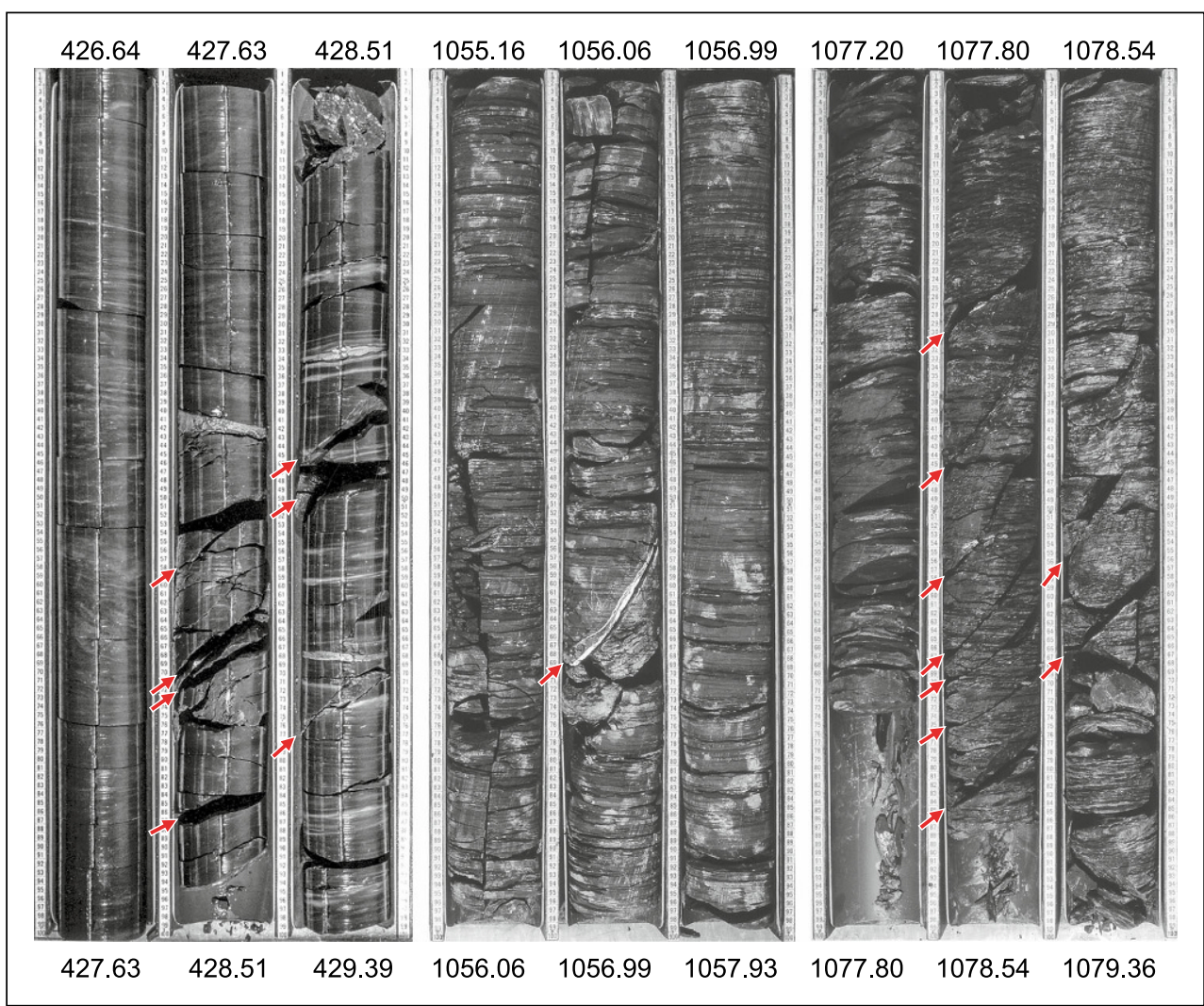

In the Opalinus Clay of the Mont Terri Rock Laboratory, which has a higher porosity compared with Benken due to lower maximum burial (see above), $\mathrm{K}$ tends to be somewhat higher and reaches values up to $7 \cdot 10^{-12} \mathrm{~m} / \mathrm{s}$ (Jaeggi et al. 2014; Yu et al. 2017) (Fig. 2). Values $\geq 10^{-11} \mathrm{~m} / \mathrm{s}$ may reflect relaxation of stresses around underground structures. Results from hydraulic tests in an inclined borehole crossing the entire Opalinus Clay (Yu et al. 2017) show higher values (in the order of $10^{-12} \mathrm{~m} / \mathrm{s}$ ) for the Opalinus Clay shaly facies than for its sandy facies (in the order of $10^{-13} \mathrm{~m} / \mathrm{s}$ ), which is attributed to diagenetic cementation of the latter. Such a trend cannot be recognised in a compilation of previous tests (Jaeggi et al. 2014; Fig. 18).

In many of the boreholes in the Mont Terri Rock Laboratory and in the deep boreholes of Northern Switzerland (Benken, Riniken, Schafisheim), intervals with large and small fault zones were also hydraulically tested (for example at Riniken and Schafisheim, see Fig. 3). The K values of these intervals do not differ significantly from those of undisturbed sections (Fig. 2) and are evidence of the excellent self-sealing capacity of the Opalinus Clay (Bock et al. 2010).

Numerous hydraulic conductivity measurements on cores parallel and perpendicular to bedding have been performed in the laboratory under various confining pressures (selected values are shown in Fig. 2). All data and the corresponding references are compiled in Nagra (2014b,
Dossier VI, Table 2.5-2). An anisotropy in hydraulic conductivity due to bedding is largely the result of microscopic heterogeneity (orientation of clay platelets, diagenetic cementation of thin silty and sandy layers). The anisotropy coefficient varies in the order of $1-10$, depending on the sedimentary fabric (Nagra 2002a, Ch. 5.8). An average value of $5\left(\mathrm{~K}_{\mathrm{H}}=5 \times \mathrm{K}_{\mathrm{V}}\right)$ was chosen as the reference value for radionuclide transport models for safety case considerations at formation scale (Nagra 2002a, Table 9.32, 2014b, Dossier VI, Ch. 4.7.2.1).

\section{Large-scale ventilation test}

A long-term ventilation test has been performed in the Mont Terri URL in a $10 \mathrm{~m}$ long unlined microtunnel with a diameter of $1.3 \mathrm{~m}$. The test can be considered as a large-scale pumping test in which the humidity increase of injected dry air, i. e. the outflow rate of vapour, is measured. An average hydraulic conductivity of $2.5 \cdot 10^{-13} \mathrm{~m} / \mathrm{s}$ of the tested block of Opalinus Clay, including several small faults, was estimated using appropriate models (Mayor et al. 2007; value plotted in Fig. 2). 
Fig. 4 Geological cross-section along the Mont Russelin highway tunnel (extract from Fig. 1 of Mazurek and De Haller (2017), after Bureau Technique Norbert (1993)). Despite extensive faulting of the Opalinus Clay, no traces of water inflows have been detected

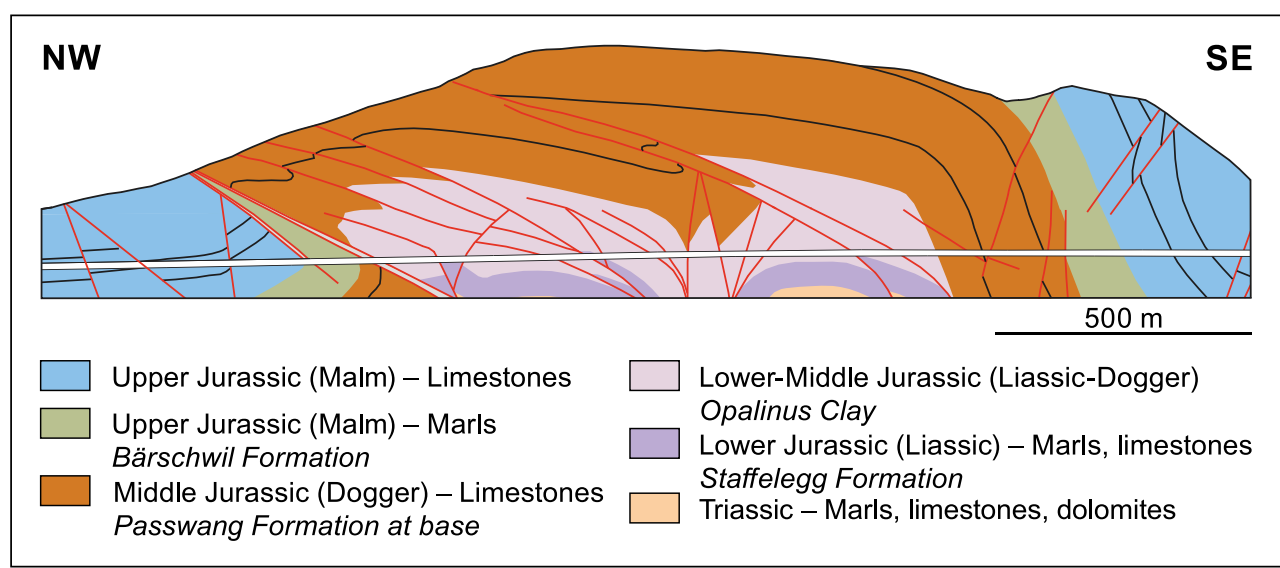

\section{Hydrogeological observations in underground structures}

Hydrogeological observations in more than $6000 \mathrm{~m}$ of tunnel sections in the Opalinus Clay, mostly in the Jura Foldand-Thrust Belt, occasionally show small water inflows at depths of less than $200 \mathrm{~m}$, generally associated with faults (Gautschi 2001). Where information is available, the waters are always saline. No water inflows or damp patches have been reported from sections with an overburden of more than $200 \mathrm{~m}$. The visual recognition of inflows in tunnels depends on various factors such as ventilation, humidity and local hydraulic gradients. The detection limit for transmissivities of discrete inflows at faults in ventilated tunnels is in the range $\mathrm{T}=10^{-9}-10^{-10} \mathrm{~m}^{2} / \mathrm{s}$ (Eugster and Senger 1994); in sections with no or low ventilation (e.g. tunnel end) much lower inflows would probably be detectable.

More recent observations in the Mont Terri Rock Laboratory showed isolated indications of localised water flow in the Opalinus Clay - so-called wet spots - with a maximum overburden up to $300 \mathrm{~m}$ (Müller and Leupin 2012). Their localisation does not show any systematic correlation with mineralogy, lithology or facies of the Opalinus Clay, and only a partial correlation with brittle structures could be found. The inflow rates in boreholes in different facies types of the Opalinus Clay which intersect wet spots are often in the range of a few $10 \mathrm{~s}$ of $\mathrm{ml} /$ day in the shaly and sandy facies. The inflows delivered porewater for periods of months to years. The inflow rates can also change with time, particularly during excavation work in the rock laboratory. This points to stress redistributions and associated poromechanical effects (e.g. squeezing of water due to local compaction). An exceptional inflow rate of up to $450 \mathrm{ml} /$ day was measured in a sandy carbonate-rich facies which has not been observed in the siting regions in Northern Switzerland (Vogt 2013). The chemical composition of the porewaters of wet spots follows the general distribution pattern of the data for Mont Terri porewaters, i. e. they do not represent chemical anomalies (see e.g. Mazurek et al. 2010a, 2010b; Vogt 2013).

In the exploration tunnel of the Mont Russelin highway tunnel crossing the Jura Fold-and-Thrust Belt, more than $1000 \mathrm{~m}$ of Opalinus Clay with numerous faults with an overburden of 300-400 m were penetrated by an open mode tunnel boring machine (Fig. 4). During excavation, detailed hydrogeological mapping at the 1:100 scale focusing on indications of even minor water inflow and damp patches was performed (Bureau Technique Norbert 1992). No dripping water or wet spots were detected in the Opalinus Clay section. The very low transmissivity of the faults is attributed to a very effective self-sealing capacity of Opalinus Clay at high overburden.

\section{Comparison with data from other clay rocks}

In a compilation of hydraulic conductivity data from various rock types (Appel and Habler 2002), values from numerous packer tests in clays/claystones with an overburden $>200 \mathrm{~m}$ are $\leq 3.3 \cdot 10^{-11} \mathrm{~m} / \mathrm{s}$ (except for one test from $480 \mathrm{~m}$ with a value of $2.1 \cdot 10^{-10} \mathrm{~m} / \mathrm{s}$ ). The hydraulic conductivity values measured in undeformed and deformed Opalinus Clay at depths below the near-surface decompaction zone (Fig. 2) are generally consistent with the experience from other clay rocks.

A compilation of 127 packer tests conducted in sedimentary strata in Nagra's deep boreholes in Northern Switzerland and at the Wellenberg site in the Helvetic Alps in various geological units (Nagra 2009) shows a clear trend of decreasing hydraulic conductivity $\mathrm{K}$ with increasing clay mineral content (Nagra 2014b, Dossier VI, Fig. 2.5-7; only data from depths below the near-surface decompaction zone were considered). Specifically, it can be shown that, for clay mineral contents $>25$ wt. $-\%$, K reduces to values $<10^{-9} \mathrm{~m} / \mathrm{s}$, and for clay mineral contents of $>40$ wt.- $\%$ to values of $<10^{-11} \mathrm{~m} / \mathrm{s}$.

Jolley et al. (2007) compiled data from a large number of permeability tests on fault rock in cores from a large 
depth range from the Brent Province (North Sea) as a function of clay mineral content. All samples with clay contents $>40$ wt.- $\%$ yielded $\mathrm{K}$ values $\leq 10^{-12} \mathrm{~m} / \mathrm{s}$ (original permeability data transferred into hydraulic conductivity values, see Nagra 2014b, Dossier VI, Fig. 2.5-8).

Mazurek et al. (2008) show that, for clay rocks, there is a positive correlation between porosity and the logarithm of hydraulic conductivity for porosities larger than ca. 5\%. However, for highly compacted clay formations with smaller porosities, the trend is broken and effective hydraulic conductivity may increase sharply. This is probably due to the fact that highly overconsolidated clay rocks lose their plasticity and their swelling potential and hence their self-sealing capacity. In the hydraulic conductivity vs. porosity diagram of Mazurek et al. (2008), the K values of Opalinus Clay plot in the lower range of hydraulic conductivities measured for clay rocks.

\section{Clay-rich confining units above and below the Opalinus Clay as supplementary migration barriers}

Above and below the Opalinus Clay, a series of low-permeability clay-rich or evaporitic formations are found between the host rock and the regional Jurassic and Triassic limestone aquifers in Northern Switzerland. Particularly in a vertical, but also in a lateral, direction these confining units act as supplementary radionuclide transport barriers (Nagra 2014b). The confining units locally contain a few metres of thick sandy, calcareous or dolomitic layers that represent potential water-conducting pathways for radionuclides. The effect of the confining units is that radionuclides that may not have decayed during transport through the Opalinus Clay host rock will only reach the biosphere after a further considerable time delay (Nagra 2002b, Ch. 7.4.6).

\section{Diffusion properties}

\section{Laboratory and field experiments}

Diffusion coefficients for Opalinus Clay were measured in the laboratory using $0.8-2 \mathrm{~cm}$ thick discs of rock, taking into account the effect of confining pressure, sample depth, sample orientation and temperature (Van Loon et al. 2003; Van Loon 2014; Van Loon and Mibus 2015). Data are available for HTO (tritiated water = mainly ordinary $\mathrm{H}_{2} \mathrm{O}$ plus ${ }^{3} \mathrm{HOH}$ in trace amounts), ${ }^{36} \mathrm{Cl}^{-},{ }^{125} \mathrm{I}^{-},{ }^{22} \mathrm{Na}^{+},{ }^{85} \mathrm{Sr}^{2+}$ and ${ }^{134} \mathrm{Cs}^{+}$ and relate mostly to transport perpendicular to bedding, with some information on transport parallel to bedding. Besides values for effective diffusion coefficients $D_{e}$, the accessible porosity $\varepsilon$ for each species can also be derived from the experiments with conservative species. Opalinus Clay data for anions and HTO are shown in Fig. 5 in comparison

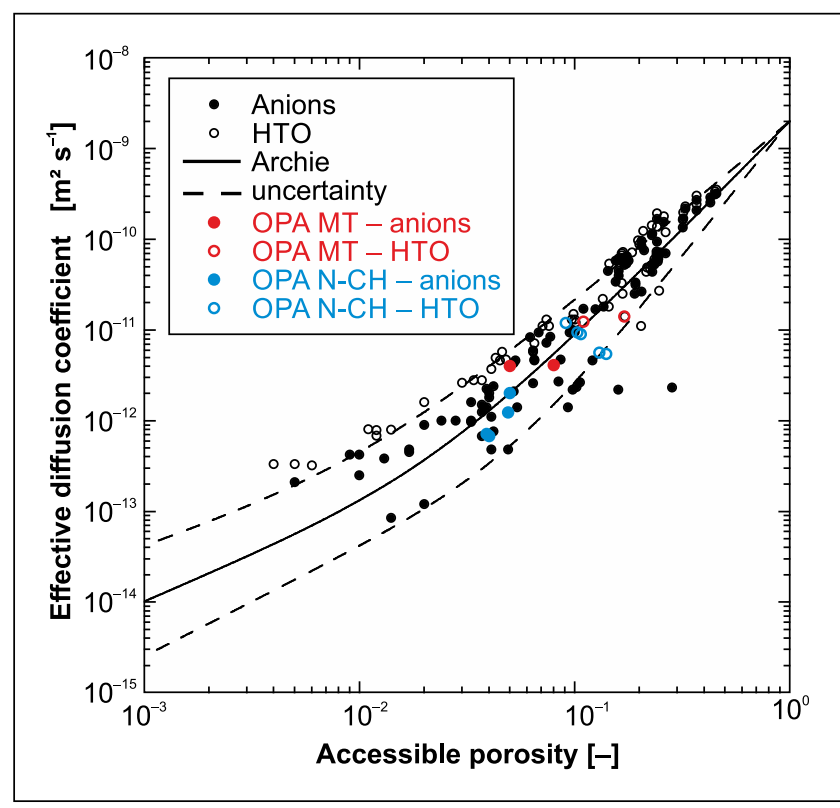

Fig. 5 Relationship between the effective diffusion coefficient (perpendicular to bedding) and the diffusion-accessible porosity for HTO and anions $\left(\mathrm{Cl}^{-}\right.$and $\left.\mathrm{I}^{-}\right)$. Modified Fig. 3 from Van Loon and Mibus (2015). Highlighted Opalinus Clay samples are from the Mont Terri URL (MT) and from deep boreholes in Northern Switzerland $(\mathrm{N}-\mathrm{CH})$, black symbols represent values from other clay rocks. The curves represent the extended Archie's relation, data were taken from the literature (for details see original paper)

with data from other clay rocks. Samples from Northern Switzerland show somewhat lower effective diffusion coefficients and porosities than those from the Mont Terri URL, which is attributed to the deeper maximum burial of the Opalinus Clay in Northern Switzerland.

In situ diffusion coefficients for $\mathrm{HTO},{ }^{125} \mathrm{I}^{-},{ }^{22} \mathrm{Na}^{+}$and some other species were measured during field experiments in the Mont Terri Rock Laboratory (Van Loon et al. 2004; Wersin et al. 2006, 2008; Soler et al. 2008, 2013); these mostly relate to transport parallel to bedding. In the experiments, which extended over one to four years, diffusion distances of up to $30 \mathrm{~cm}$ (depending on species) were reached, i. e. around one order of magnitude more than in the laboratory experiments. The laboratory and in situ values are consistent and therefore do not show any scale dependence in the range $1-30 \mathrm{~cm}$ (see compilation of all in situ and lab values in Nagra 2014b, Dossier VI, Tab. 2.6-1). From the numerous measurements perpendicular and parallel to the bedding, an anisotropy factor of around 4 can be derived for the diffusion coefficients. In a recent experiment (Gimmi et al. 2014), anisotropy ratios were determined in field experiments. For HTO and ${ }^{22} \mathrm{Na}^{+}$, the anisotropy factor is around 5; for the iodide anion it is around 4. 
Fig. 6 Distribution of chloride in the Opalinus Clay and surrounding units and results from a large-scale diffusion model at formation scale (slightly modified after Mazurek et al. (2011), combined with the upper part of Fig. 1 from Mazurek and De Haller (2017)), see explanations in the text. Geological legend see Fig. 4

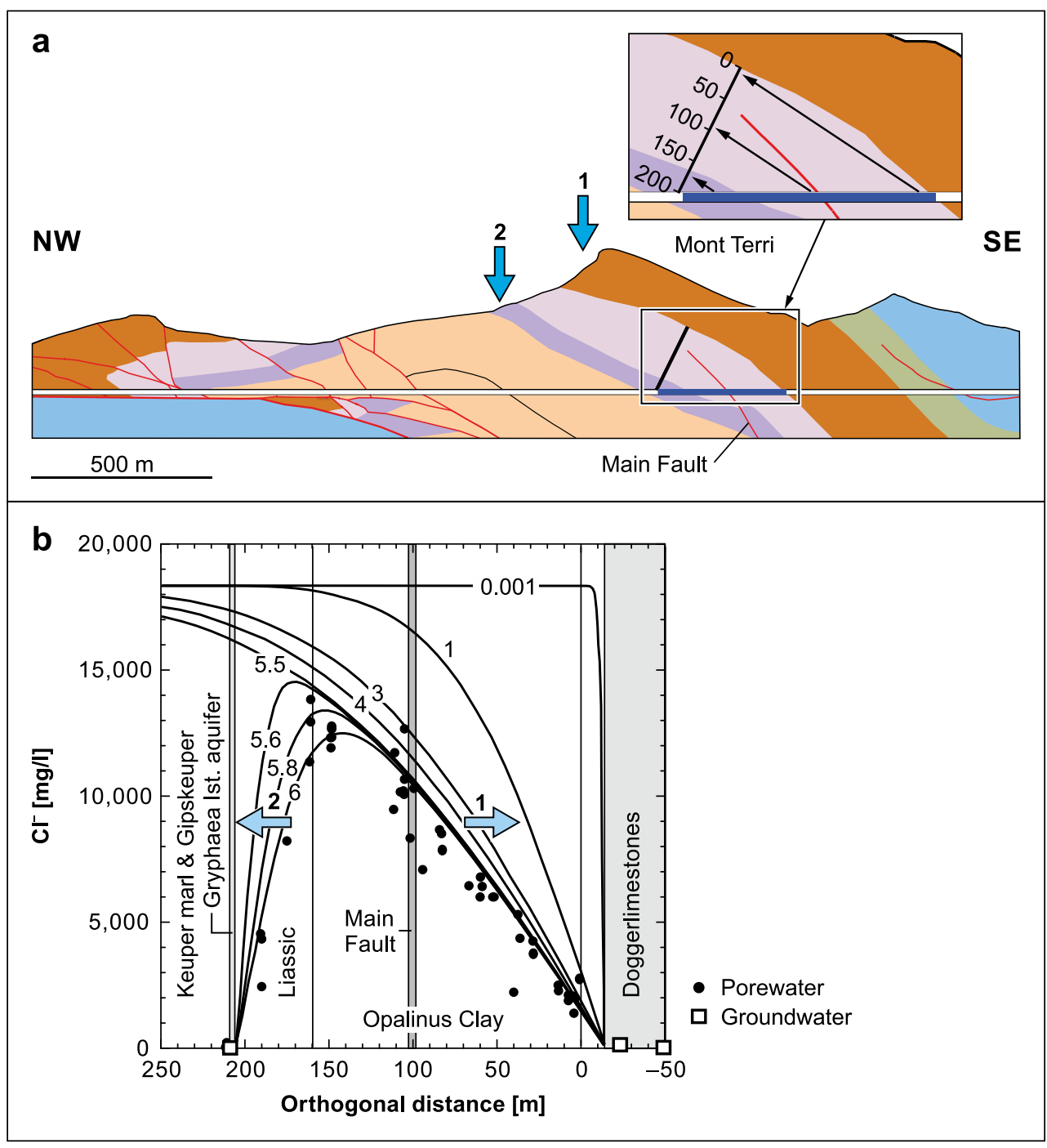

\section{Natural tracer profiles}

From the spatial distribution of porewater tracers (e. g. $\delta^{18} \mathrm{O}$, $\left.\delta^{2} \mathrm{H}, \mathrm{Cl}^{-}, \mathrm{He}\right)$ in the Opalinus Clay and in the clay-rich confining units in the Benken borehole, in the Mont Terri URL and in the Mont Russelin tunnel in Switzerland, Gimmi et al. (2007), Mazurek et al. $(2009,2011)$ and Koroleva et al. (2011) estimated the diffusion times needed for the build-up of the present-day tracer profiles using model calculations. In all cases, the shapes of the profiles can be explained by diffusion acting as the dominant transport process over periods of several hundreds of thousands to several millions of years and at the length scales of the profiles.

The most broadly based case study is that for the chloride profile through the Opalinus Clay in the southern limb of the Mont Terri anticline (Fig. 6a and b). Diffusion coefficients from small-scale laboratory experiments were used for all model calculations. These were performed considering recharge of meteoric water into the upper (Dogger) aquifer (dark blue arrow 1 in Fig. 6a) at a time when the clay-rich formation covering the Dogger aquifer was removed by erosion. At a later stage, when erosion cut through Opalinus Clay elsewhere and exposed underlying strata, recharge of meteoric water in the lower (Liassic) aquifer was initiated (dark blue arrow 2). This means that out-diffusion of chloride from the Opalinus Clay into the upper aquifer started long before that towards the underlying aquifer (light blue arrows 1 and 2 in Fig. 6b). The outdiffusion times into both aquifers were treated as fit parameters in the model calculations (Mazurek et al. 2011). As shown in Fig. 6b, a fit that well reproduces the observed asymmetry of the $\mathrm{Cl}^{-}$contents is obtained when the upper aquifer is activated at $6 \mathrm{Ma}$ and the lower aquifer at $0.5 \mathrm{Ma}$. These times are within the geologically plausible range of activation times, taking into account the time of the formation of the Jura Fold-and-Thrust Belt and landscape evolution (detailed discussion in Mazurek et al. 2011). Mazurek et al. (2011) also explored effects of additional advection 
in the direction normal to the contacts to the aquifers on the shapes and evolution times of the tracer profiles. They found that model fits considering continuous advection are worse than those based on diffusion alone, and advection velocities $\geq 4 \cdot 10^{-13} \mathrm{~m} / \mathrm{s}$ in either direction are inconsistent with the data.

Although information concerning the palaeohydrogeological boundary conditions determined by tectonic and landscape evolution does contain uncertainties, it is concluded from the consistency between the calculated buildup times and the independent palaeohydrogeological evidence that the small-scale diffusion coefficients are applicable on the formation scale, and that the permeability of the Opalinus Clay is also very low at this scale.

\section{Summary and conclusions}

In Switzerland, the Opalinus Clay formation has been selected as the first-priority host rock for a deep geological repository for both low- and intermediate-level and highlevel radioactive waste.

The properties of the Opalinus Clay that are relevant from the viewpoint of long-term safety can be summarised as follows:

- Below a near-surface decompaction zone with elevated hydraulic conductivity (up to $10^{-4} \mathrm{~m} / \mathrm{s}$ ), the hydraulic conductivity is very low $\left(\sim 10^{-13} \mathrm{~m} / \mathrm{s}\right)$ and diffusion is the dominant transport mechanism, with advection playing a secondary role at best; clay-rich confining units over- and underlying the Opalinus Clay host rock act as a supplementary barrier to migrating radionuclides.

- Faults in the Opalinus Clay do not represent preferential flow paths, which is attributed to an efficient self-sealing mechanism.

- The self-sealing capacity of the Opalinus Clay minimises the effects of perturbations caused by the repository (excavation damaged zone around underground structures) or by potentially induced or reactivated fractures in the far future.

- Stable, reducing geochemical conditions prevail and, due to its high clay mineral content, the host rock has favourable sorption properties.

The main conclusions are supported by multiple lines of evidence demonstrating consistency among hydraulic properties (tests and observations at various scales, comparisons with data from other clay rocks), porewater geochemistry, laboratory and in situ diffusion experiments, the distribution of natural tracers across the Opalinus Clay as well as smalland large-scale diffusion models and the derived conceptual understanding of solute transport.
Acknowledgements During the last two decades I profited from numerous stimulating and helpful discussions with colleagues from Switzerland and abroad related to the topics presented in this paper. Due to the limited space, only a small part of our discussions are reflected here. Thank you so much for sharing your experience with me. Most of you will find your names as first authors in the reference list below, except for Agnès Vinsot, Andra (in situ porewater characterisation), Pierre de Cannière, FANC (redox conditions in Opalinus Clay), Horst Geckeis, KIT (aquatic chemistry of actinides) and Paul Marschall, Nagra (hydraulic testing of Opalinus Clay).

The critical reviews and useful comments of Adrian Bath (Intellisci, UK), Martin Mazurek (University of Bern) and Piet Zuidema (Nagra) are gratefully acknowledged.

Many thanks to Bruno Kunz for his support in the preparation of the graphics, Linda McKinley for improvements of the English and Ingrid Stober for the editorial handling.

Open Access This article is distributed under the terms of the Creative Commons Attribution 4.0 International License (http:// creativecommons.org/licenses/by/4.0/), which permits unrestricted use, distribution, and reproduction in any medium, provided you give appropriate credit to the original author(s) and the source, provide a link to the Creative Commons license, and indicate if changes were made.

\section{References}

AkEnd: Auswahlverfahren für Endlagerstandorte. Empfehlungen des AkEnd - Arbeitskreis Auswahlverfahren Endlagerstandorte (AkEnd), Deutschland (2002)

Altmaier, M., Vercouter, T.: Aquatic chemistry of the actinides: aspects relevant to their environmental behavior. In: Poinssot, C., Geckeis, H. (eds.) Radionuclide behavior in the natural environment, pp. 44-69. Woodhead, Oxford (2012)

Altmann, S., Tournassat, C., Goutelard, F., Parneix, J.-C., Gimmi, T., Maes, N.: Diffusion-driven transport in clayrock formations. Appl Geochem 27, 463-478 (2012)

Appel, D., Habler, W.: Quantifizierung der Wasserdurchlässigkeit von Gesteinen als Voraussetzung für die Entwicklung von Kriterien für die Grundwasserbewegung. Phase 2: Auswertung der Datensätze für die Kriterienentwicklung. Arbeitskreis Auswahlverfahren Endlagerstandorte (AkEnd), Hannover (2002)

Appelo, C.A.J., Wersin, P.: Multicomponent diffusion modelling in clay systems with application to the diffusion of tritium, iodide and sodium in Opalinus Clay. Environ Sci Technol 41, 5002-5007 (2007)

Baeyens, B., Thoenen, T., Bradbury, M.H., Marques Fernandes, M.: Sorption data bases for argillaceous rocks and bentonite for the Provisional Safety Analyses for SGT-E2. Nagra Tech. Rep. NTB 12-04. Nagra, Wettingen (2014a)

Baeyens, B., Marques Fernandes, M., Bradbury, M.H.: Comparison of sorption measurements on argillaceous rocks and bentonite with predictions using the SGT-E2 approach to derive sorption data bases. Nagra Tech. Rep. NTB 12-05. Nagra, Wettingen (2014b)

Beauheim, R.L.: Hydraulic conductivity and head distributions in the host rock formations of the proposed siting regions. Nagra Arbeitsbericht NAB. Nagra, Wettingen, pp 13-13 (2013)

Berner, U.: Solubility of radionuclides in a bentonite environment for provisional safety analyses for SGT-E2. Nagra Tech. Ber. NTB 14-06. Nagra, Wettingen (2014a)

Berner, U.: Solubility of radionuclides in a concrete environment for provisional safetyanalyses for SGT-E2. Nagra Tech. Ber. NTB 14-07. Nagra, Wettingen (2014b) 
Bock, H., Dehandschutter, B., Martin, C.D., Mazurek, M., de Haller, A., Skoczylas, F., Davy, C.: Self-sealing of fractures in argillaceous formations in the context of geological disposal of radioactive waste - review and synthesis. OECD/NEA 6184. OECD Nuclear Energy Agency, Paris (2010)

Bradbury, M.H., Berner, U., Curti, E., Hummel, W., Kosakowski, G., Thoenen, T.: The Long Term Geochemical Evolution of the Nearfield of the HLW Repository. Nagra Tech. Rep. NTB 12-01. Nagra, Wettingen (2014)

Bureau Technique Norbert: Marnes Aaléniennes - étude géologique et hydrogéologique dans la galerie pilote du Mont Russelin. Relevée 1:100. Unpubl. Nagra Interner Bericht (1992)

Bureau Technique Norbert: Tunnel du Mont Russelin - Profil en long géologique. Unpublished document (1993)

ENSI: Sicherheitstechnisches Gutachten zum Vorschlag der in Etappe 3 weiter zu untersuchenden geologischen Standortgebiete. Sachplan geologische Tiefenlager Etappe 2. Eidgenössisches Nuklearsicherheitsinspektorat ENSI, Brugg (2017)

Eugster, S., Senger, R.K.: Nachweisgrenze von Transmissivität eines transmissiven Elements (TE) an der ventilierten Stollenwand. Unpubl. Nagra Interner Bericht (1994)

Ferrari, A., Favero, V., Manca, D., Laloui, L.: Geotechnical characterization of core samples from the geothermal borehole Schlattingen SLA-1 by LMS/EPFL. Nagra Arbeitsbericht NAB 12-50. Nagra, Wettingen (2012)

Garitte, B., Köhler, S., Müller, H.R., Sakaki, T., Vogt, T., Weber, H.P., Holl, M., Plötze, M., Wetzig, V., Tschudi, M., Jenni, H., Vietor, T., Carrera, E., Wieland, G., Teodori, S., García-Siñeriz Martínez, J.L., Jacobs, F.: Horizontal bentonite backfilling and concrete plug for the Full-Scale Emplacement (FE) experiment at the Mont Terri URL: requirements, design, instrumentation and emplacement. In: Hansen, J. (ed.) DOPAS (Contract Number: FP7 - 323273) Deliverable $\mathrm{n}^{\circ}$ 7.3 D7.3 DOPAS 2016 Proceedings. Euratom Research and Training Programme on Nuclear Energy , 7th framework programme (2016)

Gautschi, A.: Hydrogeology of a fractured shale (Opalinus clay): implications for deep geological disposal of radioactive wastes. Hydrogeol J 9, 97-107 (2001)

Gimmi, T., Waber, H.N., Gautschi, A., Rübel, A.: Stable water isotopes in pore water of Jurassic argillaceous rocks as tracers for solute transport over large spatial and tem-poral scales. Water Resour Res 43, W04410 (2007)

Gimmi, T., Leupin, O.X., Eikenberg, J., Glaus, M.A., Van Loon, L.R., Waber, N.H., Wersin, P., Hao Wang, H.A.O., Grolimund, D., Borca, C.N., Dewonck, S., Wittebroodt, C.: Anisotropic diffusion at the field scale in a 4-year multi-tracer diffusion and retention experiment - I: insights from the experimental data. Geochim Cosmochim Acta 125, 373-393 (2014)

Grambow, B.: Geological disposal of radioactive waste in clay. Elements 12, 239-245 (2016)

Hekel, U.: Hydrogeologische Erkundung am Beispiel des Opalinustons (Unteres Aalenium). Tüb. Geowiss. Arb., Reihe C, Nr. 18, Diss. Geowiss. Fakultät, Univ. Tübingen (1994)

Jaeggi, D., Bossart, P., Wymann, L.: Kompilation der lithologischen Variabilität und Eigenschaften des Opalinus-Ton im Felslabor Mont Terri. Expertenbericht ENSI 33/489. Eidgenössisches Nuklearsicherheitsinspektorat ENSI, Brugg (2014)

Jolley, S.J., Dijk, H., Lamens, J.H., Fisher, Q.J., Manzocchi, T., Eikmans, H., Huang, Y.: Faulting and fault sealing in production simulation models. Brent Province, northern North Sea. Pet Geosci 13, 321-340 (2007)

Kommission Lagerung hochradioaktiver Abfallstoffe: Abschlussbericht, K-Drs. 268 (2016)

Koroleva, M., Alt-Epping, P., Mazurek, M.: Large-scale tracer profiles in a deep claystone formation (Opalinus Clay at Mont Russelin, Switzerland): implications for solute transport processes and transport properties of the rock. Chem Geol 280, 284-296 (2011)
Mäder, U.: Reference pore water for the Opalinus Clay and 'Brown Dogger' for the provisional safety-analysis in the framework of sectoral plan - interim results (SGT-ZE). Nagra Arbeitsbericht NAB 09-14. (2009)

Mayor, J.-C., Garcia-Siñeriz, J.L., Velasco, M., Gómez-Hernández, J., Lloret, A., Matray, J.-M., Coste, F., Giraud, A., Rothfuchs, T., Marschall, P., Roessli, U., Mayer, G.: Ventilation experiment in Opalinus clay for the disposal of radioactive waste in underground repositories. In: Bossart, P., Nussbaum, C. (eds.) Mont Terri project - heater experiment, engineered barrier emplacement experiment and ventilation experiment Report of the Swiss Geol. Survey $\mathrm{N}^{\circ} 1$. pp. 181-240. (2007)

Mazurek, M., Hurford, A.J., Leu, W.: Unravelling the multi-stage burial history of the Swiss Molasse Basin: Integration of apatite fission track, vitrinite reflectance and biomarker isomerisation analysis. Basin Res 18, 27-50 (2006)

Mazurek, M., Gautschi, A., Marschall, P., Vigneron, G., Lebon, P., Delay, J.: Transferability of geoscientific information from various sources (study sites, underground rock laboratories, natural analogues) to support safety cases for radioactive waste repositories in argillaceous formations. Phys Chem Earth 33, S95-S105 (2008)

Mazurek, M., Alt-Epping, P., Bath, A., Gimmi, T., Waber, H.N.: Natural tracer profiles across argillaceous formations: the CLAYTRAC project. NEA No. 6253. OECD Nuclear Energy Agency, Paris (2009)

Mazurek, M., Koroleva, M., Vietor, T., Müller, H.: WS-H experiment: petrophysical properties and anion contents in samples of deformed Opalinus Clay from the galerie 08. Mont Terri Project, Technical Note TN 2009-60. (2010a)

Mazurek, M., Meier, D., Müller, H.: WS-H experiment: Geological, petrophysical and geochemical characterisation of drillcores from borehole BHG-B11. Mont Terri Project, Technical Note TN 201022. (2010b)

Mazurek, M., Alt-Epping, P., Bath, A., Gimmi, T., Waber, H.N., Buschaert, S., De Cannière, P., De Craen, M., Gautschi, A., Savoye, S., Vinsot, A., Wemaere, I., Wouters, L.: Natural tracer profiles across argillaceous formations. Appl Geochem 26, 1035-1064 (2011)

Mazurek, M., Oyama, T., Wersin, P., Alt-Epping, P.: Pore-water squeezing from indurated shales. Chem. Geol. 400, 106-121 (2015)

Mazurek, M., De Haller, A.: Pore-water evolution and solute-transport mechanisms in Opalinus clay at Mont Terri and Mont Russelin (canton Jura, Switzerland). Swiss J Geosci 110, 129 (2017). doi:10.1007/s00015-016-0249-9

Müller, H., Leupin, O.: WS-H Experiment (Investigation of Wet spots): observation, first experimental results, and a short presentation of possible hypotheses regarding the origin of these waters. Mont Terri Project, Technical Note TN 2012-96. (2012)

Nagra: Sondierbohrung Benken. Untersuchungsbericht. Nagra Tech. Ber. NTB 00-01. Nagra, Wettingen (2001)

Nagra: Projekt Opalinuston. Synthese der geowissenschaftlichen Untersuchungsergebnisse. Entsorgungsnachweis für abgebrannte Brennelemente, verglaste hochaktive sowie langlebige mittelaktive Abfälle. Nagra Tech. Ber. NTB 02-03. Nagra, Wettingen (2002a)

Nagra: Project Opalinus Clay. Safety report. Demonstration of disposal feasibility for spent fuel, vitrified high-level waste and long-lived intermediate-level waste (Entsorgungsnachweis). Nagra Tech. Rep. NTB 02-05. Nagra, Wettingen (2002b)

Nagra: Vorschlag geologischer Standortgebiet für das SMA- und das HAA-Lager - Darlegung der Anforderungen, des Vorgehens und der Ergebnisse (Hauptbericht). Nagra Tech. Ber. NTB 08-03. Nagra, Wettingen (2008a) 
Nagra: Vorschlag geologischer Standortgebiet für das SMA- und das HAA-Lager - Geologische Grundlagen. Nagra Tech. Ber. NTB 08-04. Nagra, Wettingen (2008b)

Nagra: Vorschlag geologischer Standortgebiete für das SMA- und das HAA-Lager - Darstellung der hydraulischen Durchlässigkeit versus Tongehalt in Sedimentgesteinen aus Tiefbohrungen in der Nordschweiz und am Wellenberg im Hinblick auf die Beurteilung der SGT-Kriterien „Hydraulische Barrierenwirkung“ und „Freisetzungspfade“. Nagra Arbeitsbericht NAB 09-28. (2009)

Nagra: Beurteilung der geologischen Unterlagen für die provisorischen Sicherheitsanalysen in SGT Etappe 2. Nagra Tech. Ber. NTB 1001. Nagra, Wettingen (2010)

Nagra: SGT Etappe 2: Vorschlag weiter zu untersuchender geologischer Standortgebiete mit zugehörigen Standortarealen für die Oberflächenanlage. Geologische Grundlagen. Sicherheitstechnischer Bericht zu SGT Etappe 2. Sicherheitstechnischer Vergleich und Vorschlag der in Etappe 3 weiter zu untersuchenden geologischen Standortgebiete. Nagra Tech. Ber. NTB 14-02. Nagra, Wettingen (2014a)

Nagra: SGT Etappe 2: Vorschlag weiter zu untersuchender geologischer Standortgebiete mit zugehörigen Standortarealen für die Oberflächenanlage. Geologische Grundlagen. Dossiers I - VIII. Nagra Tech. Ber. NTB 14-02. Nagra, Wettingen (2014b)

Nagra: SGT Etappe 2: Vorschlag weiter zu untersuchender geologischer Standortgebiete mit zugehörigen Standortarealen für die Oberflächenanlage. Charakteristische Dosisintervalle und Unterlagen zur Bewertung der Barrierensysteme. Nagra Tech. Ber. NTB 14-03. Nagra, Wettingen (2014c)

Nagra: The Nagra Research, Development and Demonstration (RD\&D) Plan for the Disposal of Radioactive Waste in Switzerland. Nagra Tech. Rep. NTB 16-02. Nagra, Wettingen (2016)

Pearson, F.J.: Gas porewater equilibrium (PC-C) experiment: geochemical equilibrium modelling of water chemical data and comparison with results of earlier Mont Terri experiments. Mont Terri Project, Technical Note TN 2007-42. (2009)

Pearson, F.J., Waber, H.N.: Origin and evolution of pore-water solutes in the very-low permeability Opalinus Clay, Switzerland. In: Cidu, R. (ed.) Proc. 10th Internat. Symp. Water-Rock Interaction - WRI-10 Villasimius. pp. 1355-1358. Balkema, Lisse (2001)

Pearson, F.J., Arcos, D., Bath, A., Boisson, J.-Y., Fernández, A.M., Gaebler, H.E., Gaucher, E.C., Gautschi, A., Griffault, L., Hernan, P., Waber, H.N.: Geochemistry of water in the Opalinus clay formation at the Mont Terri rock laboratory - synthesis report. Reports of the federal office of water and geology (FOWG). Geology Series No. 5. (2003)

Pearson, F.J., Tournassat, C., Gaucher, E.: Biogeochemical processes in a clay formation in-situ experiment: part E - equilibrium controls on chemistry of pore water from the Opalinus Clay, Mont Terri Underground Research Laboratory, Switzerland. Appl Geochem 26, 990-1008 (2011)

Romero, E., Gómez, R.: Water and air permeability tests on deep core samples from Schlattingen SLA-1 borehole. Nagra Arbeitsbericht NAB 13-51. Nagra, Wettingen (2013)

Swiss Federal Office of Energy (SFOE): Sectoral plan for deep geological repositories - conceptual part. Department of the Environment, Transport, Energy and Communications/SFOE, Bern (2008)

Soler J.M., Samper, J., Yllera, A., Hernández, A., Quejido, A., Fernández,M., Yang, C., Naves, A. Hernán, P., Wersin, P.: The DI-B in situ diffusion experiment at Mont Terri: Results and modeling. Physics and Chemistry of the Earth, Parts A/B/C 33:S196-S207 (2008)
Soler, J.M., Wersin, P., Leupin, O.X.: Modeling of $\mathrm{Cs}^{+}$diffusion and retention in the DI-A2 experiment (Mont Terri). Uncertainties in sorption and diffusion parameters. Appl Geochem 33, 191-198 (2013)

Van Loon, L.R.: Effective diffusion coefficients and porosity values for argillaceous rocks and bentonite: measured and estimated values for the provisional safety analyses for SGT-E2. Nagra Tech. Rep. NTB 12-03. Nagra, Wettingen (2014)

Van Loon, L.R., Mibus, J.: A modified version of Archie's law to estimate effective diffusion coefficients of radionuclides in argillaceous rocks and its application in safety analysis studies. Appl Geochem 59, 85-94 (2015)

Van Loon, L.R., Soler, J.M.: Diffusion of HTO, ${ }^{36} \mathrm{Cl}^{-},{ }^{125} \mathrm{I}^{-}$and ${ }^{22} \mathrm{Na}^{+}$ in Opalinus Clay: Effect of confining pressure, sample orientation, sample depth and temperature. Nagra Tech. Rep. NTB 0307. Nagra, Wettingen (2003)

Van Loon, L.R., Wersin, P., Soler, J.M., Eikenberg, J., Gimmi, T., Hernan, P., Dewonck, S., Savoye, S.: In situ diffusion of HTO, ${ }^{22} \mathrm{Na}^{+}$, $\mathrm{Cs}^{+}$and $\mathrm{I}^{-}$in Opalinus Clay at the Mont Terri underground rock laboratory. Radiochim Acta 92, 757-763 (2004)

Vogt, T.: WS-I experiment: borehole BBB-3: outflow measurements and hydrochemical analyses. Mont Terri Project, Technical Note TN 2013-01. (2013)

Wersin, P., Johnson, L.H., Schwyn, B., Berner, U., Curti, E.: Redox conditions in the near field of a repository for SF/HLW and ILW in opalinus clay. Nagra Tech. Rep. NTB 02-13. Nagra, Wettingen (2003)

Wersin, P., Baeyens, B., Bossart, P., Cartalade, A., Dewonck, S., Eikenberg, J., Fierz, T., Fisch, H.R., Gimmi, T., Grolimund, D., Hernan, P., Möri, A., Savoye, S., Soler, J., Van Dorp, F., Van Loon, L.: Long-term diffusion experiment (DI-A): Diffusion of HTO, $\mathrm{I}^{-},{ }^{22} \mathrm{Na}^{+}$and $\mathrm{Cs}^{+}$: Field activities, data and modelling. Mont Terri Techn. Rep. TR 2003-06. (2006)

Wersin, P., Soler, J.M., Van Loon, L., Eikenberg, J., Baeyens, B., Grolimund, D., Gimmi, T., Dewonck, S.: Diffusion of HTO, $\mathrm{Br}^{-}, \mathrm{I}^{-}, \mathrm{Cs}^{+},{ }^{85} \mathrm{Sr}^{2+}$ and ${ }^{60} \mathrm{Co}^{2+}$ in a clay formation: results and modelling from an in situ experiment in Opalinus Clay. Appl Geochem 23, 678-691 (2008)

Wersin, P., Leupin, O.X., Mettler, S., Gaucher, E., Mäder, U., De Cannière, P., Vinsot, A., Gabler, H.E., Kunimaro, T., Kiho, K., Eichinger, L.: Biogeochemical processes in a clay formation in situ experiment: part A - overview, experimental design and water data of an experiment in the Opalinus Clay at the Mont Terri Underground Research Laboratory, Switzerland. Appl Geochem 26, 931-954 (2011a)

Wersin, P., Stroes-Gascoyne, S., Pearson, F.J., Tournassat, C., Leupin, O.X., Schwyn, B.: Biogeochemical processes in a clay formation in situ experiment: part $\mathrm{G}$-key interpretations \& conclusions. Implications for repository safety. Appl Geochem 26, 1023-1034 (2011b)

Wersin, P., Mazurek, M., Waber, H.N., Mäder, U.K., Gimmi, T., Rufer, D., De Haller, A.: Rock and porewater characterisation on drillcores from the Schlattingen borehole. Nagra Arbeitsbericht NAB 12-54. (2013)

Wetzel, A., Allia, V.: Der Opalinuston in der Nordschweiz: Lithologie und Ablagerungsgeschichte. Eclogae Geol Helv 96, 451-469 (2003)

Yu, C., Matray, J.-M., Gonçalvès, J., Jaeggi, D., Gràsle, W., Wieczorek, K., Vogt, T., Sykes, E.: Comparative study of methods to estimate hydraulic parameters in the hydraulically undisturbed Opalinus Clay (Switzerland). Swiss J Geosci 110(1), 85-104 (2017). doi:10.1007/s00015-016-0257-9 